\title{
БЕЗОПАСНОСТЬ ДОРОЖНОГО ДВИЖЕНИЯ В СВЕРДЛОВСКОЙ ОБЛАСТИ: АНАЛИЗ ПРОБЛЕМЫ И ИЗУЧЕНИЕ ОБЩЕСТВЕННОГО МНЕНИЯ
}

\begin{abstract}
Аннотация: В статье анализируется состояние проблемы безопасности дорожного движения в России и Свердловской области. С позищии конщепџий социальной интеграчии и социальной справедливости ведется обоснованный поиск механизмов решения проблемы безопасности дорожного движения в регионе. Приводятся доказательства зарубежных и отечественных теоретически исследований и соииальных практик. Объектом исследования является изучение общественного мнения населения России и Свердловской области по таким вопросам, как: состояние безопасности дорожного движения, эффективность путей решения проблемы безопасности дорожного движения. Проводится сравнительный анализ данных соичологических исследований, проведенных авторами в 2012-2013 гг., с данныли официальной статистики и Всероссийского исследования, проведенного ВЦИОМ в марте 2013 г. Предлагается в качестве решения заявленной проблемы партнерство государства, бизнеса, гражданского общества, в том числе государственно-частное партнерство при внедрении на территории Свердловской области системы фото- $u$ видеофиксаиии нарушений ПДД в автоматическом режиме. Аргументируется данное предложение прогнозируемым социально-экономическим эффектом, при этом акцент ставится на достижение таких социально-значимых задач, как: повыщение безопасности дорожного движения, сохранение жизни и здоровья всех его участников.
\end{abstract}

Ключевые слова: безопасность дорожного движения, сочиально-демографическая безопасность, государственно-частное партнерство, межсекторное партнерство, фиксация нарушений, транспортные риски, социальная интеграция, социальная солидарность, дорожно-транспортное происшествие, общественное мнение.

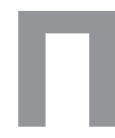

роблема безопасности дорожного движения за последние годы приобрела не просто абстрактную актуальность, а, по мнению специалистов ${ }^{1}$, составляет угрозу социально-демографической и национальной безопасности страны и ее регионов, поскольку касается ежедневных реалий жизни каждого человека, не важно в какой роли выступающего - водителя, пешехода или пассажира. По оценкам между-

\footnotetext{
Стенограмма совещания у Председателя Правительства Российской Федерации Д.А. Медведева в формате Открытого правительства по вопросам повышения безопасности дорожного движения 29 марта 2013 г. Режим доступа: http://www. opobdd.ru/home/713--29-----
}

народных экспертов, состояние безопасности дорожного движения в Российской Федерации, «является критическим». ${ }^{2}$

По данным доклада «Безопасность дорожного движения в России: современное состояние и неотложные меры по улучшению состояния», подготовленного Высшей школой экономики в 2013 г., «Россия (наряду с Китаем, Индией, Бразилией, Камбоджей, Египтом, Кенией, Мексикой, Турцией и Вьетнамом) входит в группу «Risky States - 10»десятку стран с высоким уровнем транспортных

\footnotetext{
2 Road Safety Performance National Peer review: Russian Federation, Update 2010, OECD. Режим доступа: http://www. internationaltransportforum.org/Pub/pdf/11Russia.pdf.
} 


\section{Национальная безопасность - № 2(31) • 2014}

рисков, на которую приходится более половины от общего числа смертей на дорогах мира» .

При этом, важно понимать, что вопрос безопасности дорожного движения не может рассматриваться сам по себе - вне связи с вопросами развития различного рода пространственных и общественных взаимодействий и отношений — поскольку представляет собой соединение технических, человеческих, социальных, административных и прочих акторов.

Именно такой ракурс изучения темы безопасности дорожного движения позволяет увидеть и понять проблемы социальной и профессиональной мобильности населения, пространственной сегрегации, социального напряжения, субурбанизации, социально-экономического развития крупных городов, травматических переживаний и экономических потерь, связанных с ДТП, изменения функционального назначения городских пространств и др.

Так, по мнению французского урбаниста А. Лефевра, «циркуляция движения становится одной из основных функций общества, обусловливая приоритет парковочных мест, улиц и дорог по отношению к другим соображениям». И далее: «Автомобиль поработил повседневность, навязав ей свои законы. . . способствует дезинтеграции городской жизни ... и усиливает особый «психоз» водителя ... и не мешает большинству людей «рисковать», ибо машина с ее свитой раненых и погибших, с ее кровавым следом - это все, что остается от повседневной жизни с ее жалким рационом волнения и опасности».

В этой связи необходимо отметить, что международными организациями и сообществами (такими, как ВО3 - Всемирная организация здравоохранения, ЕКМТ - Европейская конференция министров транспорта и Всемирный банк) вопрос обеспечения безопасности дорожного движения рассматривается как необходимое условие обеспечения социального равенства в обществе.

«Только императивное соблюдение тотального равенства прав, обязанностей и ответственности всех участников дорожного движения без исключения позволяет снизить транспортные риски» . Преимущества тех или иных лиц в дорожном движении не совместимы с системой моральных ценностей и могут привести к моральной дезориентации социума, его аномии, и в итоге - к разрушению целостности общества.

Так, по данным социологического опроса сотрудников ГИБДДГУ МВД России, проведенном ВЦИОМ в марте 2013 года, «к категории «неприкасаемых» относится 20-40\% участников дорожного движения в г. Москве, и до $10 \%$ в регионах... Совокупное количество участников дорожного движения, привилегии которых «оформляются» посредством светотехнических и звуковых устройств, специальных номерных серий, различного рода талонов, пропусков и т.П., исчисляется в настоящее время сотнями тысяч».

Рост с 2000 г. в России ее регионах коэффициентов смертности населения моложе трудоспособного и трудоспособного возраста, инвалидизации населения от транспортных несчастных случаев, показателей числа погибших к числу пострадавших, социально-экономических издержек от ДТП, а также интенсивный рост числа погибших в ДТП детей заставляет осуществлять поиск эффективных механизмов, технологий организации и управления безопасностью дорожного движения (Рис.1).

Ситуация в сфере безопасности дорожного движения в Свердловской области мало отличается от описанной выше ситуации в России в целом. Так, по данным Росстата, Управления ГИБДД ГУ МВД по Свердловской области ${ }^{4}$, за 10 лет (2003 - 2012 гг.) в Свердловской области произошло 75481 ДТП, в которых пострадали 107761 человек, из них: 8773 человека погибли, 98988 человек - получили ранения) (Рис.2).

При этом, необходимо принимать во внимание ряд фактов. Во-первых, официальная статистика учитывает только те ДТП, в которых серьезно пострадали или погибли люди. Во-вторых, в официальной российской статистике (до 2009 г.) погибшим считался тот гражданин, кто умирал в течение 7 дней после ДТП. С 2009 г. — в течение 30 дней (в соответствии с международными стандартами). В-третьих, официальная статистика разных ведомств отличается между собой - статистические данные по числу погибших и пострадавших в ДТП Министерства здравоохранения РФ выше, чем статистические данные МВД РФ. Все вышеизложенное позволяет предположить, что количество ДТП и тяжесть их последствий в Свердловской области гораздо выше, чем по данным официальной статистики.

Что касается ущерба, нанесенного экономике Свердловской области, то его ориентировочно можно просчитать, опираясь на предложенную ГНИИ авто-

\footnotetext{
3 Lefebvre H. Everyday Life in the Modern World. New Brunswick: Transaction Publishers, 1990. — p. 100.

4 Lefebvre H. Everyday Life in the Modern World. New Brunswick: Transaction Publishers, 1990. — p. 101.
} 


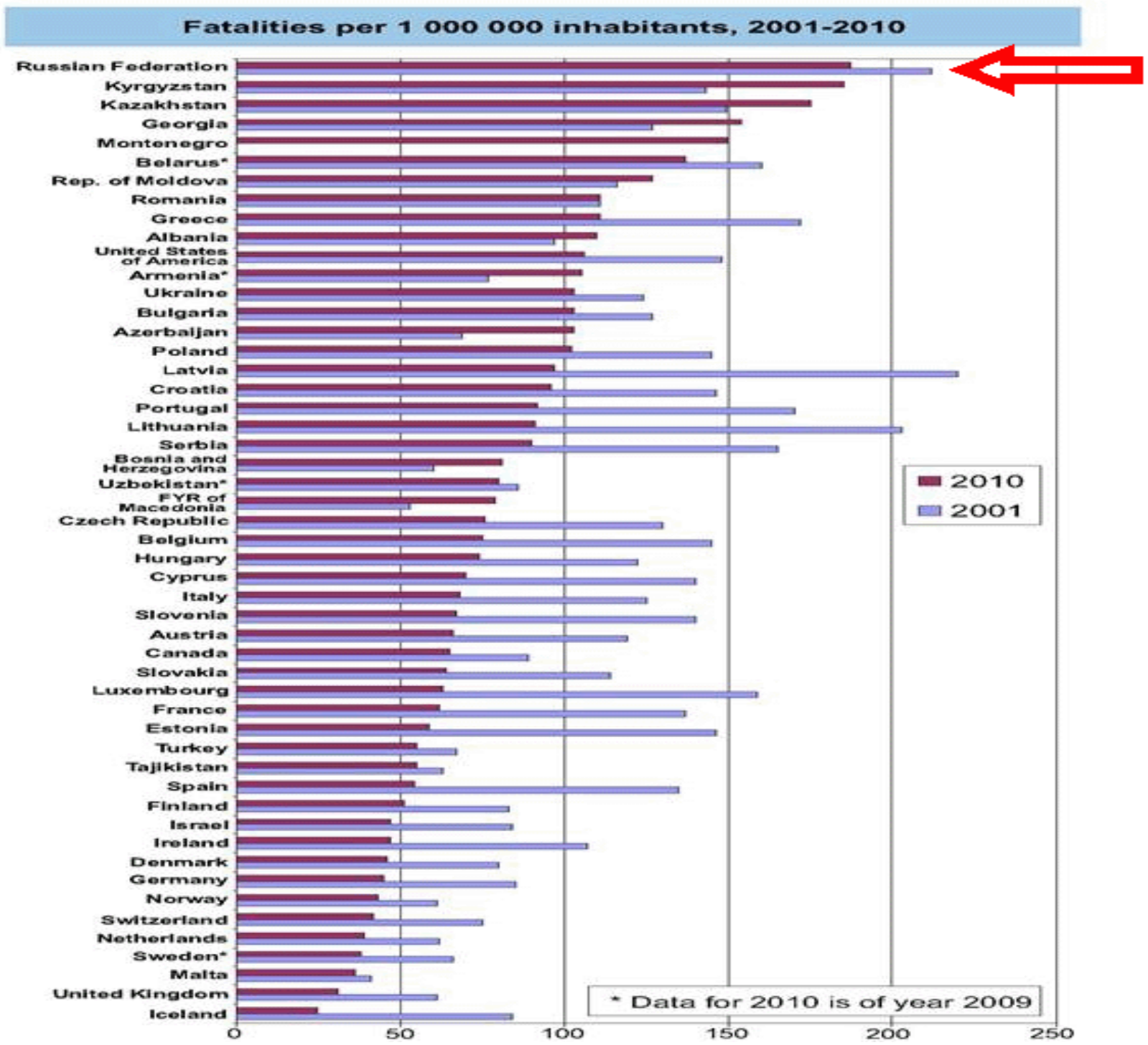

Рис 1. Динамика числа погибших на 1000000 жителей в 2001- 2010 гг.

Источник: The UNECE Road Traffic Accidents Statistics 2011.

Режим доступа: http://rusrand.ru/ideas/k-zasedaniju-obschestvennogo-soveta-rosavtodora

мобильной промышленности методику определения стоимости человеческой жизни, согласно которой она в настоящее время оценивается в 300,0 тыс. долларов США (или 9,9 млн. рублей по текущему курсу) ${ }^{5}$.

Центр стратегических исследований гражданской защиты МЧС России предлагает значение стоимости

\footnotetext{
5 Сколько стоит человеческая жизнь? Интервью с директором Научного центра «Безопасность дорожного движения» ГНИИ автомобильной промышленности, к.т.н. А.П. // Евразия, Вести. - 2007. - №2. Режим доступа: http://www.eav.ru/publ1. php?publid=2007-02a14
}

среднестатистической жизни исчислять в размере 320,0 $-340,0$ тыс. долларов США (или 10,5 - 11,2 млн. рублей по текущему курсу), исходя из расчета экономической полезности среднестатистического человека.

Официальную статистику иллюстрируют результаты проведенного в 2012-2013гг. в Свердловской области исследования общественного мнения населения по вопросам безопасности дорожного движения.

Респонденты проявили солидарность по вопросу своего субъективного ощущения безопасности и защищенности на дорогах города: 44\% опрошенных чувствуют себя незащищенными, $11 \%$ - абсолютно 


\section{Национальная безопасность - № 2(31) • 2014}

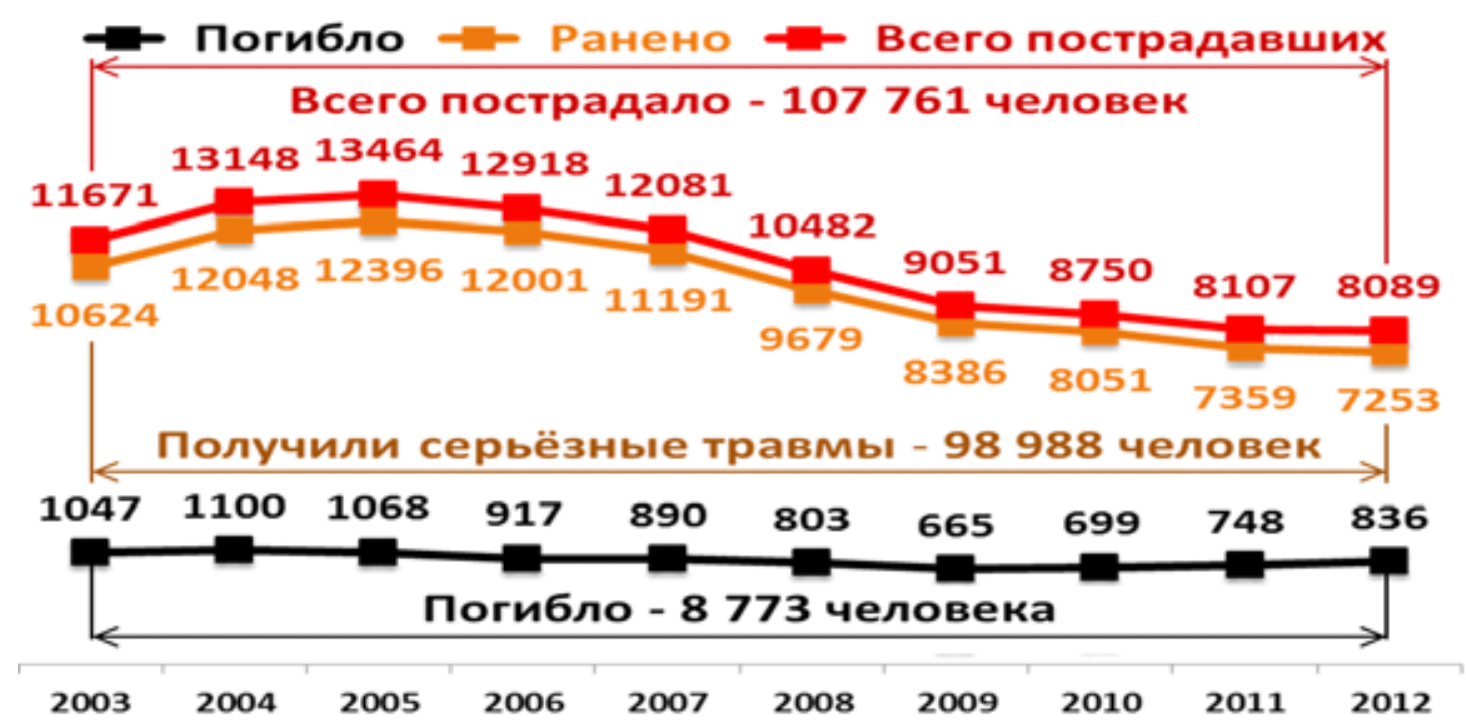

Рис.2. Динамика дорожно-транспортного травматизма в Свердловской области (2003-2012 гг.)

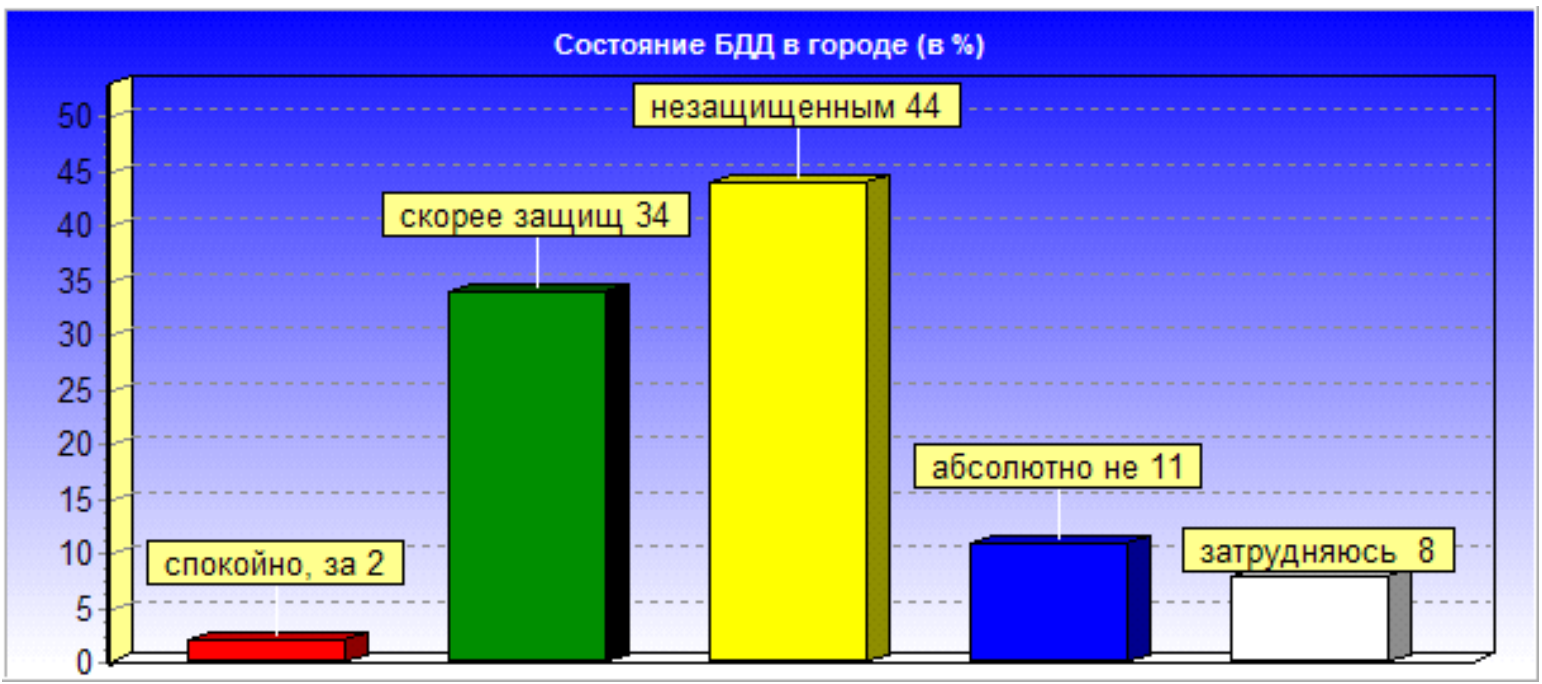

Рис. 3. Распределение ответов на вопрос о состоянии защищенности респондентов в сфере дорожного движения, \% от ответивших

не защищенными (Рис. 3). При этом, 36\% горожан уверены в том, что за последние 3 года состояние безопасности дорожного движения в городе и в России в целом ухудшилось.

В ходе нашего исследования среди причин, ухудшающих состояние безопасности дорожного движения, респонденты назвали: низкую дисциплину водителей (22,3\% от ответивших), плохое состояние дорог (21,2\% от ответивших) и плохую организацию движения (14,5\% от ответивших).

Ответы не противоречат официальной статистике, согласно которой 75\% всех ДТП обусловлены «нарушением правил дорожного движения со стороны водителей», ${ }^{6}$ а также результатам указанного выше Всероссийского опроса ВЦИОМ, проведённого в марте 2013 г. в 42 областях, краях и республиках России, согласно которому $47 \%$ россиян ключевым фактором нарушения правил дорожного движения считают низкий уровень культуры участников дорожного движения, независимо от их социального статуса 7 .

\footnotetext{
6 Шабанова М.А.Социоэкономика. - М.: Экономика, 2012.—c.35.

7 Материалы Всероссийского исследования ВЦИОМ «Безопасность дорожного движения глазами его участников, сотрудников ГИБДД и общества». Режим доступа: http://wciom. $\mathrm{ru} / \mathrm{index} . \mathrm{php} ? \mathrm{id}=459 \&$ uid $=113800$
} 


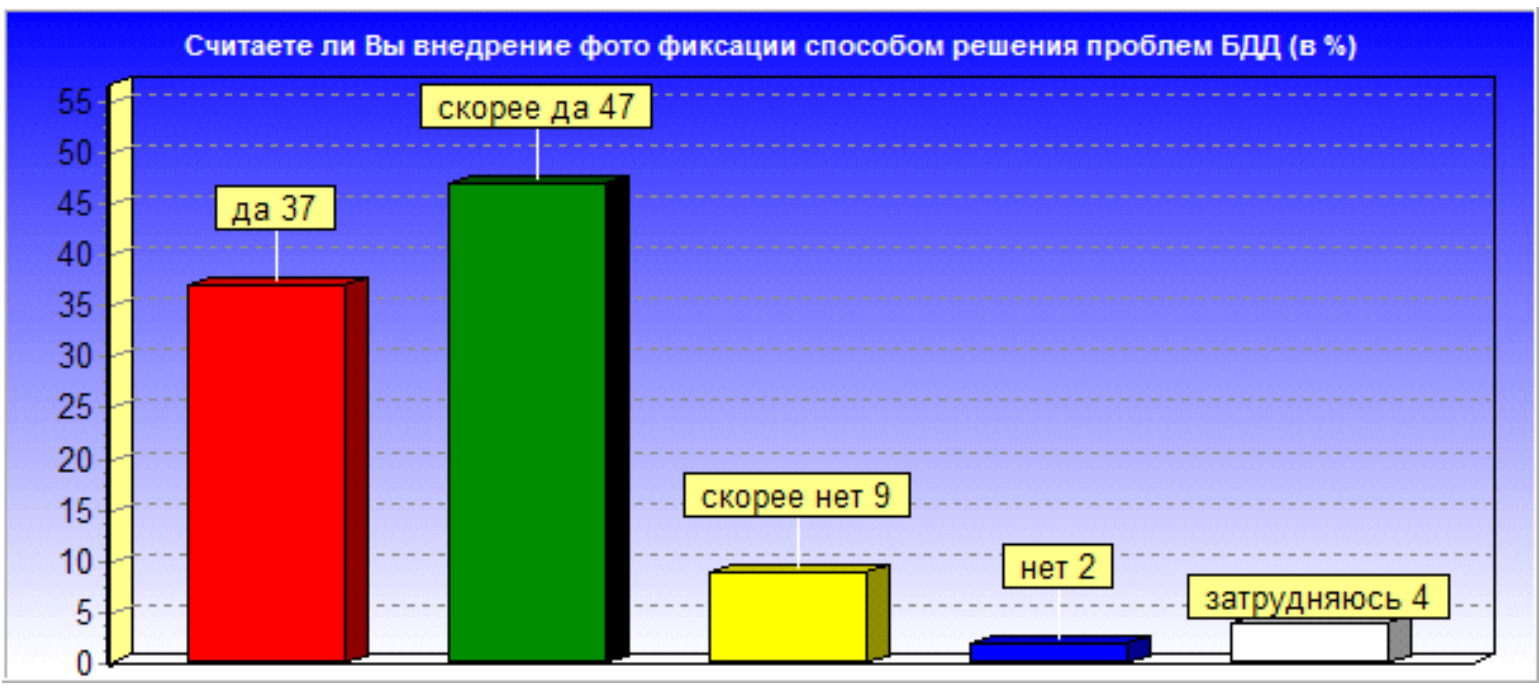

Рис. 4. Распределение ответов на вопрос «Станет ли внедрение фотои видеофиксации нарушений ПДД в автоматическом режиме способом решения проблем безопасности дорожного движения», \% от ответивших

Среди же причин неэффективности решения проблемы безопасности дорожного движения, респонденты назвали: незаинтересованность власти в решении проблем безопасности ( $24 \%$ от ответивших), отсутствие системных усилий всех участников (23\% от ответивших).

По мнению респондентов, потенциал мер принуждения к безопасной езде, выражающихся, прежде всего, в повышении размеров штрафов за грубые нарушения ПДД, себя исчерпал. $52,2 \%$ ответивших считают, что существующая система штрафов не дисциплинирует водителей, поскольку срабатывает «эффект привыкания».

Ответившие считают, что необходимо внедрять современные стандарты и технологии «пассивной безопасности» на дорогах. Среди таких технологий респонденты в ходе опроса назвали внедрение системы фото- и видеофиксации нарушений ПДД в автоматическом режиме (44,4\% от ответивших). $52 \%$ ответивших заявили, что положительно относятся к уже установленным камерам фото- и видеофиксации нарушений ПДД в г. Екатеринбурге.

$84 \%$ ответивших считают, что внедрение камер фото- и видеофиксации нарушений ПДД в автоматическом режиме способно улучшить состояние безопасности дорожного движения (Рис.4).

Аналогичная ситуация наблюдается и в результатах Всероссийского опроса ВЦИОМ $86 \%$ россиян, считают, что видеонаблюдение и использование системы ГЛОНАСС являются эффективными в обеспечении безопасности дорожного движения ${ }^{8}$.

Что касается эффективности использования систем фото- и видеофиксации нарушений ПДД в автоматическом режиме за рубежом, то опыт Великобритании, Франции и др. стран показывает рост выявляемости количества нарушений ПДД, сокращение уровня смертности в результате ДТП в результате внедрения камер контроля скорости в 1,9 раза (Рис.5 и 6). Об этом же свидетельствует и опыт субъектов РФ, внедряющих на своей территории системы фото- и видеофиксации нарушений ПДД (Рис.7).

Внедрение систем фото- и видеофиксации нарушений ПДД в автоматическом режиме в России осуществляется на основании поправок в Кодекс РФ об административных правонарушениях, внесенных в 2008 году. Вместе с тем, на сегодняшний день отсутствует система стандартизации данных технических средств, которая является необходимым условием их использования. Также, законодательство РФ не обеспечивает эффективной системы взимания штрафов и административных ограничений для водителей - неплательщиков. Существуют проблемы и в функционировании Центров автоматизированной

\footnotetext{
8 Материалы Всероссийского исследования ВЦИОМ «Безопасность дорожного движения глазами его участников, сотрудников ГИБДД и общества». Режим доступа: http://wciom. $\mathrm{ru} /$ index.php?id $=459 \&$ uid $=113800$
} 
DOI: $10.7256 / 2073-8560.2014 .2 .10856$

При цитировании этой статьи сноска на dоі обязательна

Национальная безопасность - № 2(31) • 2014

— Полицейскими

- Камерами скорости

$\leadsto$ Bcero

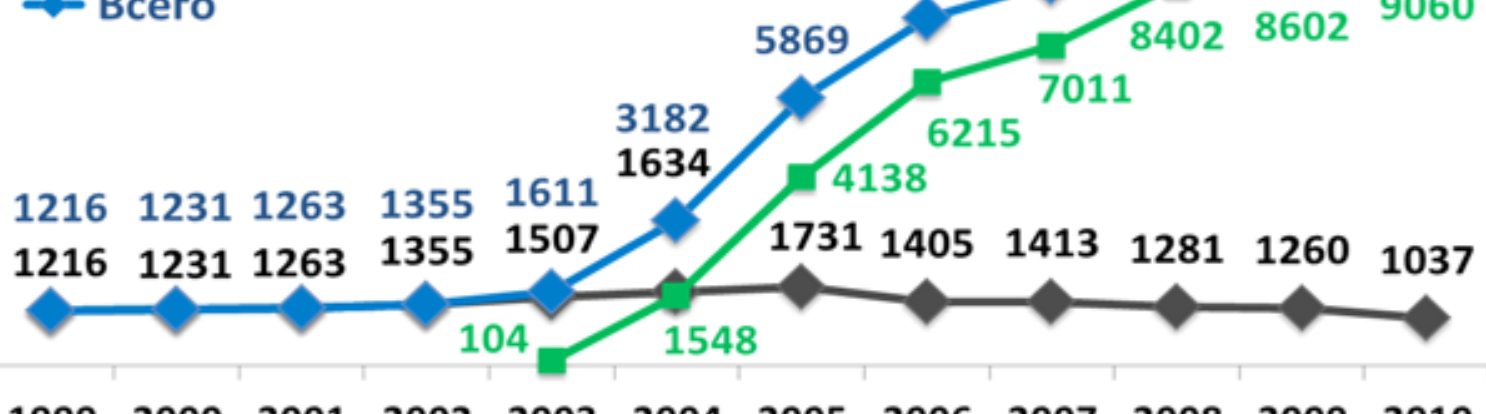

199920002001200220032004200520062007200820092010

Рис. 5. Динамика выявляемости количества нарушений ПДД, связанных с превышением скорости, во Франции (1999-2010 гг.)

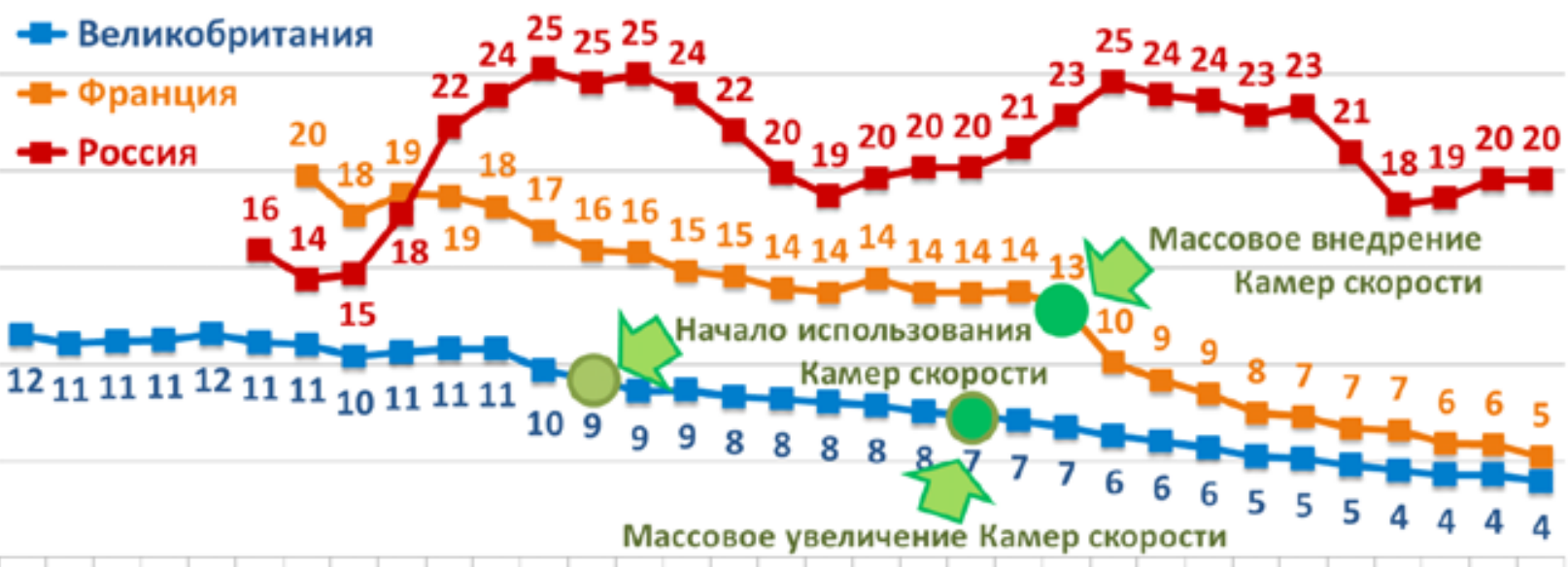

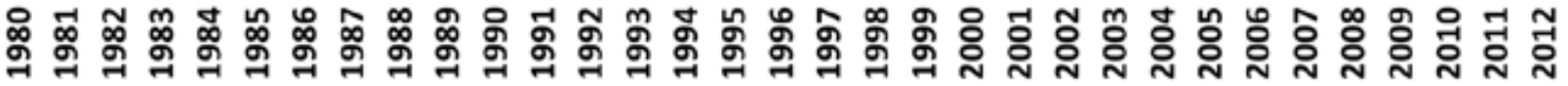

Количество погибших в результате ДТП на 100000 населения

Рис.6. Динамика числа погибших в связи с внедрением камер

контроля скорости (Великобритания, Франция, 1980-2011 гг.)

\section{Московская область 글 Татарстан}

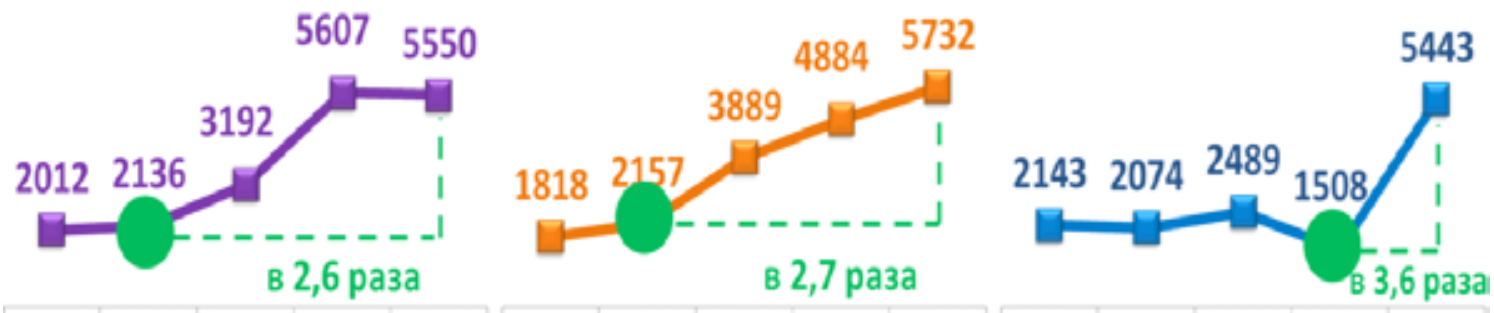

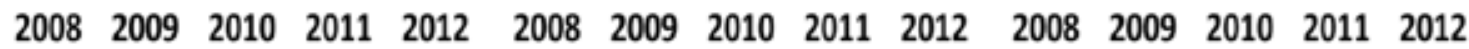

Рис.7. Динамика выявляемости количества нарушений ПДД, связанных с превышением скорости, в субъектах РФ (2008 -2012 гг.) 
фиксации административных правонарушений. «Нередко главными цифрами отчетов о работе систем фото- и видеофиксации становятся не данные о снижении числа ДТП, а суммы, заработанные на штрафах». Кроме того, существующая система фото- и видеофиксации «не обеспечивает защиту граждан от ошибок автоматических специальных технических средств» ${ }^{9}$. Все это не позволяет в должной мере решать основную задачу внедрения системы фото- и видеофиксации нарушений ПДД в автоматическом режиме - повышение безопасности дорожного движения, сохранение жизни и здоровья всех его участников.

Особенности развития современного общества таковы, что большинство проблем не разрешимы без активного участия граждан, без механизмов межсекторного партнерства: власть-бизнес-общество. На сегодняшний день важны не просто законодательные инициативы и инфраструктурные решения, но и их общественная экспертиза и оценка, а также инвестиционная составляющая реализации со стороны бизнеса.

Зарубежные исследователи, в том числе О. Johansson, изучающие вопросы транспортной географии, на многих примерах развития западных городов в рамках партнерства доказывают, что «политика, осуществляемая альянсом местного правительства и бизнеса, способна расширить возможности города».

$38 \%$ респондентов в нашем исследовании указали, что решение проблемы безопасности дорожного движения возможно в рамках партнерства органов власти, бизнеса и общества. По мнению ответивших, наибольший эффект в данной сфере возможен будет достигнуть благодаря партнерским, а не только силовым усилиям.

Данные нашего опроса подтверждают тезис отечественных исследователей (И.В. Мерсиянова, Л.И. Никовская, В.Н. Якимец и др.) о социальной самоорганизации и социальной консолидации как условии развития социальной интеграции общества, т.е. «способности общества координировать взаимодействие индивидов, социальных групп и общностей, от которой зависит, насколько общество способно справляться с различными проблемами». ${ }^{10}$

\footnotetext{
9 Общественный доклад «О состоянии дел в сфере организации и безопасности дорожного движения в регионах России».М.: Общественная Палата РФ, 2013. Режим доступа: http:// www.oprf.ru/discussions/newsitem/23352

10 Там же
}

В настоящее время выделяют несколько вариантов партнерства в решении той или социально значимой проблемы, в основе которых лежит понимание того, что без социальной консолидации и «со-участия» любая инициатива обречена на провал. Это и «общественно-государственное партнерство» (общество власть), «частно-общественное партнерство» (бизнес - общество), «межсекторное социальное партнерство» (власть - бизнес - общество) и «государственночастное партнерство» (власть-бизнес).

Вместе с тем, на сегодняшний день в России недооценена в полной мере роль партнерства власти, бизнес-сообщества и институтов гражданского общества в социально-экономическом развитии территорий, снижении социальной напряженности и уменьшении социального неравенства через совместное решение социально значимых задач.

Так, на конец 2013 г. в Российской Федерации отсутствуют как единое понимание и определение понятия «государственно-частное партнерство», так и сам закон РФ о государственно-частном партнерстве (ГЧП). В ряде регионов, несмотря на отсутствие федерального закона, приняты региональные законы о государственно-частном партнерстве, что в определенной мере способствует развитию механизмов ГЧП, но тормозит само становление ГЧП как института в связи с разночтением понятия, несовершенством правовой базы, превышением субъектами РФ своих полномочий (поскольку данный вопрос относится к ведению РФ), высокими финансовыми рисками в долгосрочных проектах ГЧП.

В Свердловской области принят Областной закон «Об участии Свердловской области в государственно-частном партнерстве» от 23 мая 2011 года № 28-О3 (с изменениями на 25 апреля 2012 года), в соответствии с которым, «государственно-частное партнерство - направленное на социально-экономическое развитие Свердловской области сотрудничество Свердловской области с российскими и (или) иностранными юридическими и (или) физическими лицами, осуществляемое в соответствии с соглашениями и договорами». ${ }^{11}$ Функции контроля в области ГЧП переданы Губернаторскому совету по инвестициям.

На наш взгляд, ГЧП следует рассматривать как эффективную организационно-правовую форму ис-

\footnotetext{
11 Johansson O. Inter-Urban Competition and Air Transport in the Deregulated Era: The Nashville Case. // Journal of Transport Geography. 2007. — № 15. - p. 368.
} 


\section{Национальная безопасность - № 2(31) • 2014}

полнения государством своих обязанностей перед обществом, решения общественно значимых задач и проблем (как правило, финансово затратных, капиталоемких, инфраструктурных и пр.), в основе которой лежит согласование интересов государства и бизнеса, и объединение их ресурсов.

Именно указанный ракурс рассмотрения данного понятия, позволяет оценить значимость государственно-частного партнерства в решении проблемы безопасности дорожного движения. Для внедрения на территории Свердловской области автоматизированной системы видеофиксации нарушений ПДД, по нашим подсчетам, требуется установка минимум 430 автоматических технических средств видеофиксации нарушений ПДД. Выбор мест расположения технических средств фиксации нарушений (скоростного режима, выезда на запрещающий сигнал светофора, пересечение разделительной (сплошной) полосы, запрещенная парковка и т.д.) определяется, исходя из статистических данных по количеству нарушений, принципа обеспечения общей безопасности и улучшения дорожной обстановки на территории Свердловской области, и согласования с Управлением ГИБДД ГУ МВД по Свердловской области.

Стоимость внедрения 1 технического средства, по предварительным расчетам, составляет порядка $5,8-6,0$ млн.рублей, в зависимости от стоимости строительно-монтажных и пусконаладочных работ, обслуживания и пр. расходов. Общая стоимость внедрения на территории Свердловской области автоматизированной системы видеофиксации нарушений ПДД составляет порядка 2,6 млрд. рублей.

Внедрение автоматизированной системы видеофиксации нарушений ПДД на территории Свердловской области позволит обеспечить автоматизацию всего технологического цикла видеофиксации нарушений: регистрация нарушения; выписывание штрафа; оповещение нарушителя; контроль оплаты; поступление штрафов в бюджет региона; передача дела судебным приставам для взыскания штрафа с должников; передача данных для формирования статистических показателей.

Ввод на территории региона в качестве технологии «пассивной безопасности» на дорогах автоматизированной системы видеофиксации нарушений ПДД, как показывает опыт зарубежных стран, позволяет формировать сначала общественный стереотип, а затем - и общественный императив безопасной езды, ведущий к существенному снижению транспортных рисков.

Кроме того, автоматизированная система видеофиксации нарушений ПДД будет выполнять и важную функцию сообщения всем участникам дорожного движения о включенности в происходящее и тотальном равенстве ответственности, тем самым, способствуя стабилизации социальных отношений и формированию доверия в современной социальной действительности.

В условиях дефицита бюджета Свердловской области на 2014 год, существующих правовых ограничений, а также конфликтологического дискурса в политической жизни региона последних лет, реализация задачи внедрения автоматизированной системы видеофиксации нарушений ПДД вне рамок государственно-частного партнерства, на наш взгляд, вызывает большие сомнения.

Что, в свою очередь, может отодвинуть на неопределенное время и решение проблемы обеспечения безопасности дорожного движения в Свердловской области в рамках Московской декларации, принятой по итогам Первой всемирной министерской конференции по безопасности дорожного движения (г. Москва, 20 ноября 2009 года), в соответствии с которой, «период с 2011 по 2020 гг. назван «Десятилетием действий по обеспечению безопасности дорожного движения» с целью стабилизации и последующего сокращения прогнозируемого уровня случаев смерти в результате дорожно-транспортных происшествий в мире». ${ }^{12}$ И в целом - решение таких вопросов, как: хроническое недовольство граждан существующими проблемами в организации дорожного движения и нарастание социальной напряженности в обществе.

\section{Библиография}

1. Доклад «Безопасность дорожного движения в России: современное состояние и неотложные меры по улучшению состояния». - М.: Высшая школа экономики, 2013. Режим доступа: http://opec.ru/data/20

\footnotetext{
12 Никовская Л.И., Якимец В.Н., Молокова М.А. Гражданские инициативы и модернизация России. - М.: Ключ-С, 2011. - c. 99.
} 
$13 / 03 / 27 / 1233152070 / \% \mathrm{D} 0 \% 92 \% \mathrm{D} 0 \% \mathrm{~A} 8 \% \mathrm{D} 0 \% \mathrm{AD}$ \%D0\%AD\%D0\%A1_\%D0\%91\%D0\%94\%D0\%94\%20 $\% \mathrm{D} 0 \% \mathrm{~B} 2 \% 20 \% \mathrm{D} 0 \% \mathrm{~A} 0 \% \mathrm{D} 0 \% \mathrm{BE} \% \mathrm{D} 1 \% 81 \% \mathrm{D} 1 \% 81 \% \mathrm{D} 0 \% \mathrm{~B} 8 \% \mathrm{D} 0 \% \mathrm{~B} 8 . \mathrm{pdf}$

2. Клейнер Г. Б. Экономика России как социального государства.// Россия и мир: вчера, сегодня, завтра. Политические и экономические проблемы. М.: МГИ им. Е.Р. Дашковой, 2012. Режим доступа: http://www. kleiner.ru/arpab/sgos-2012.html

3. Материалы Всероссийского исследования ВЦИОМ «Безопасность дорожного движения глазами его участников, сотрудников ГИБДД и общества». Режим доступа: http://wciom.ru/index.php?id=459\&uid=113800

4. Никовская Л. И., Якимец В. Н., Молокова М. А. Гражданские инициативы и модернизация России. - М.: Ключ-С, 2011. - $336 \mathrm{c.}$

5. Общественный доклад «О состоянии дел в сфере организации и безопасности дорожного движения в регионах России». - М.: Общественная Палата РФ, 2013. Режим доступа: http://www.oprf.ru/discussions/ newsitem $/ 23352$

6. Скворцов О. К заседанию Общественного совета при Федеральном дорожном агентстве. Заключение по проекту федеральной целевой программы «Повышение безопасности дорожного движения в 2013-2020 годах». Режим доступа: http://rusrand.ru/ideas/k-zasedaniju-obschestvennogo-soveta-rosavtodora

7. Сколько стоит человеческая жизнь? Интервью с директором Научного центра «Безопасность дорожного движения» ГНИИ автомобильной промышленности, к.т.н. А.П. Юровым // Евразия, Вести. — 2007. №2. Режим доступа: http://www.eav.ru/publ1.php?publid=2007-02a14

8. Шабанова М. А. Социоэкономика. - М.: Экономика, 2012. - 559 с.

9. Johansson O. Inter-Urban Competition and Air Transport in the Deregulated Era: The Nashville Case. // Journal of Transport Geography. 2007. — № 15.

10. Lefebvre H. Everyday Life in the Modern World. New Brunswick: Transaction Publishers, 1990.

11. Road Safety Performance National Peer review: Russian Federation, Update 2010, OECD. Режим доступа: http:// www.internationaltransportforum.org/Pub/pdf/11Russia.pdf

12. The UNECE Road Traffic Accidents Statistics 2011. Режим доступа: http://rusrand.ru/ideas/k-zasedanijuobschestvennogo-soveta-rosavtodora

13. Истратов А.А. Правовые и организационные аспекты профилактики дорожно-транспортных происшествий и нарушений правил дорожного движения личным составом органов внутренних дел // Полицейская деятельность. - 2012. - 3. - С. 20-25.

14. Баширова А.Ф., Истратов А.А. Правовое регулирование профилактики дорожно-транспортного травматизма // Полицейская деятельность. - 2012. — 2. - С. 30-34.

15. Трунов И.Л. Административно-правовое регулирование безопасности дорожного движения при использовании специальных световых и звуковых приборов. // Административное и муниципальное право. 2011. - 3. - C. 9-12.

16. Кашкина Е.В. К вопросу о состоянии детского дорожно-транспортного травматизма и роль Госавтоинспекции в его предупреждении // Полицейская деятельность. — 2011. — 6. — С. 56-61.

\section{References}

1. Doklad «Bezopasnost' dorozhnogo dvizheniya v Rossii: sovremennoe sostoyanie i neotlozhnye mery po uluchsheniyu sostoyaniya». - M.: Vysshaya shkola ekonomiki, 2013. Rezhim dostupa: http://opec.ru/data/2 013/03/27/1233152070/\%D0\%92\%D0\%A8\%D0\%AD_\%D0\%AD\%D0\%A1_\%D0\%91\%D0\%94\%D0\%94\%20 $\% \mathrm{D} 0 \% \mathrm{~B} 2 \% 20 \% \mathrm{D} 0 \% \mathrm{~A} 0 \% \mathrm{D} 0 \% \mathrm{BE} \% \mathrm{D} 1 \% 81 \% \mathrm{D} 1 \% 81 \% \mathrm{D} 0 \% \mathrm{~B} 8 \% \mathrm{D} 0 \% \mathrm{~B} 8 . \mathrm{pdf}$

2. Kleiner G. B. Ekonomika Rossii kak sotsial'nogo gosudarstva.// Rossiya i mir: vchera, segodnya, zavtra. Politicheskie i ekonomicheskie problemy. M.: MGI im. E.R. Dashkovoi, 2012. Rezhim dostupa: http://www. kleiner.ru/arpab/sgos-2012.html

3. Materialy Vserossiiskogo issledovaniya VTsIOM «Bezopasnost' dorozhnogo dvizheniya glazami ego uchastnikov, sotrudnikov GIBDD i obshchestva». Rezhim dostupa: http://wciom.ru/index.php?id=459\&uid=113800

4. Nikovskaya L. I., Yakimets V. N., Molokova M. A. Grazhdanskie initsiativy i modernizatsiya Rossii. — M.: Klyuch-S, 2011. - $336 \mathrm{~s}$. 
DOI: $10.7256 / 2073-8560.2014 .2 .10856$

При цитировании этой статьи сноска на dоі обязательна

\section{Национальная безопасность - № 2(31) • 2014}

5. Obshchestvennyi doklad «O sostoyanii del v sfere organizatsii i bezopasnosti dorozhnogo dvizheniya $\mathrm{v}$ regionakh Rossii». - M.: Obshchestvennaya Palata RF, 2013. Rezhim dostupa: http://www.oprf.ru/discussions/ newsitem $/ 23352$

6. Skvortsov O. K zasedaniyu Obshchestvennogo soveta pri Federal'nom dorozhnom agentstve. Zaklyuchenie po proektu federal'noi tselevoi programmy «Povyshenie bezopasnosti dorozhnogo dvizheniya v 2013-2020 godakh». Rezhim dostupa: http://rusrand.ru/ideas/k-zasedaniju-obschestvennogo-soveta-rosavtodora

7. Skol'ko stoit chelovecheskaya zhizn'? Interv'yu s direktorom Nauchnogo tsentra «Bezopasnost' dorozhnogo dvizheniya» GNII avtomobil'noi promyshlennosti, k.t.n. A.P. Yurovym // Evraziya, Vesti. — 2007. — №2. Rezhim dostupa: http://www.eav.ru/publl.php?publid=2007-02a14

8. Shabanova M. A. Sotsioekonomika. - M.: Ekonomika, 2012. - $559 \mathrm{~s}$.

9. Johansson O. Inter-Urban Competition and Air Transport in the Deregulated Era: The Nashville Case. // Journal of Transport Geography. 2007. — № 15.

10. Lefebvre H. Everyday Life in the Modern World. New Brunswick: Transaction Publishers, 1990.

11. Road Safety Performance National Peer review: Russian Federation, Update 2010, OECD. Rezhim dostupa: http:// www.internationaltransportforum.org/Pub/pdf/11Russia.pdf

12. The UNECE Road Traffic Accidents Statistics 2011. Rezhim dostupa: http://rusrand.ru/ideas/k-zasedanijuobschestvennogo-soveta-rosavtodora

13. Istratov A.A. Pravovye i organizatsionnye aspekty profilaktiki dorozhno-transportnykh proisshestvii i narushenii pravil dorozhnogo dvizheniya lichnym sostavom organov vnutrennikh del // Politseiskaya deyatel'nost'. — 2012. -3. - C. 20-25.

14. Bashirova A.F., Istratov A.A. Pravovoe regulirovanie profilaktiki dorozhno-transportnogo travmatizma // Politseiskaya deyatel'nost'. - 2012. - 2. - C. 30-34.

15. Trunov I.L. Administrativno-pravovoe regulirovanie bezopasnosti dorozhnogo dvizheniya pri ispol'zovanii spetsial'nykh svetovykh i zvukovykh priborov. // Administrativnoe i munitsipal'noe pravo. — 2011. — 3. — C. 9-12.

16. Kashkina E.V. K voprosu o sostoyanii detskogo dorozhno-transportnogo travmatizma i rol' Gosavtoinspektsii v ego preduprezhdenii // Politseiskaya deyatel'nost'. - 2011. - 6. - C. 56-61. 